\title{
MODERN CIVILIZATION: FROM THE ACHIEVEMENT OF HIGH TECHNOLOGIES TO THE CRISIS OF HUMANISM
}

\author{
(C) Vachit Kh. Akaev, Laila M. Ismailova \\ Grozny State Oil Technical University, \\ Grozny, Chechen Republic, Russian Federation \\ akaiev@mail.ru
}

The achievements of modern civilization associated with the use of scientific and technological achievements, high technologies that determine the development of the economy, social and cultural processes are characterized. There are also noted processes that have a negative character associated with the activities of transnational corporations that generate factors of suppression of the national interests of states, individual peoples involving them in the processes of urbanization, standardization of ethnic cultural values that disfigure traditional spiritual, cultural and moral values.

Key words: civilization, culture, high technologies, crisis of humanism.

\section{[В.Х. Акаев, Л.М. Исмаилова Современная цивилизация: от достижения высоких технологий к кри-} зису гуманизма]

Характеризуются достижения современной цивилизации, сопряженные с использованием научнотехнических достижений, высоких технологий, детерминирующих развитие экономики, социальных, культурных процессов. Отмечаются и процессы, имеющие негативный характер, связанные с деятельностью транснациональных корпораций, порождающих факторы подавления национальных интересы государств, отдельных народов, вовлекая их в процессы урбанизации, стандартизации этнических культурных ценностей, уродующих традиционные духовно-культурные и моральные ценности.

Ключевые слова: цивилизация, культура, высокие технологии, кризис гуманизма.

Vachit Kh. Akaev - Ph.D. (Advanced Doctorate) in Philosophy, Professor, Grozny State Oil Technical University, Grozny, Chechen Republic, Russian Federation.

Laila M. Ismailova - Ph.D. in Philosophy, Grozny State Oil Technical University, Grozny, Chechen Republic, Russian Federation.

Акаев Вахит Хумидович - доктор фрилософрских наук, профрессор, Грозненский государственный нефртяной технический университет, г. Грозный, Чеченская Республика, Российская Федерация.

Исмаилова Лайла Магомедовна - кандидат философрских наук, Грозненский государственный нефтяной технический университет, г. Грозный, Чеченская Республика, Российская Федерация.

Modern civilization often referred to as technogenic and formed in Europe has its own various forms of manifestation both in the West and in the East. And its technical, economic and social achievements are faced by various traditional societies at the stage of savagery, agrarian, industrial forms of socio-economic existence. The people and states that are within the framework of such forms of organization are sensitively influenced by the technogenic civilization are forced to use them and also to adapt thoroughly. The development of modern civilization is associated with the widespread usage of the results of scientific and technological progress, high technologies, which determine its essence and specificity. It is characterized by the accelerated development of the productive forces of society based on such priority areas of scientific and technological achievements as nuclear energy, microelectronics, informatics, 
robotics, biotechnology, instrumentation, aerospace, etc. The prospects for the development of our civilization are promising in connection with the discovery of high-temperature superconductivity. It is widely used, for example, in medicine, in electron tomography, in a scanner that uses the principle of nuclear magnetic resonance. In this case, the patient is only a few centimeters away from superconducting electromagnets, which create a field that allows doctors to obtain high-precision images of human body tissue in a section, which makes it possible to dispense with the use of a scalpel.

The deployment of the modern scientific and technological revolution determines the corresponding new stage of the social condition of community, in which the tasks of acquiring new knowledge, continuous education, its technological and human application will dominate. In this regard, it seems that the problems of the spiritual life of people, spiritual culture, the need for humanistic values are being actualized as never before. However, today it seems that the spiritual culture of a person and people in general began to deplete, that it no longer plays a key role in human relationships.

The peculiarity of modern civilization lies in the fact that world economic systems have been created, the corresponding processes of cooperation, concentration and globalization in the economy, politics, science and culture have taken shape. The problem of war and peace, of ecology, the energy problem, the question of health, international terrorism and the fight against them also characterize it.

The current development of information civilization as a higher stage of technogenic civilization consists in the fact that it is not identified within national boundaries, it goes beyond them to the level of interethnic, interstate formations while forming super-ethnic groups and powerful corporations. This civilization is a continuation, development of the Western type of civilization, which has gone through various stages in its development and has a powerful impact on non-Western types of civilizations which include Confucian, Japanese, Islamic, Hindu, Slavic Orthodox, Latin American and African ones. Of course, all these civilizations in their modern development exist only with the adoption of scientific, technical and technological achievements of the West. The Japanese miracle is an unprecedented economic growth after the atomic bombing of the United States of Hirsima and Nagasaki and a civilizational phenomenon of a «vaccination» of American scientific and technological achievements and technologies as well as the strictest executive production discipline and attracting "brains" and innovations into the country into the traditional Japanese culture.

Today, the Russian people, which consists of a number of peoples with different ethnic characteristics, is also one of the forms of a super-ethnos that have universal human significance influencing the cultural and spiritual development of many peoples of the world.

The process of modernization of contemporary society on an information technology basis takes place in different ways in countries and regions with different national and cultural characteristics. The new Russian model is based on the real possibilities of the material and spiritual development of our country, but at the same time it is important to take into account world civilizational tendencies. The ideals of a technogenic civilization include the ability of an individual to join freely a wide variety of social communities and corporations. Power and domination in this system of relations involves the ownership and appropriation of the results of activity in the form of goods. An important component of technogenic civilization is the special value of scientific rationality, a scientific and theoretical view of the world, which creates confidence that a person is able by controlling external circumstances to rationally arrange nature and social reality. In fact, the situation is different because humanity is in the face of global dangers, which was associated with world wars that crossed out humanistic ideals [1, p. 93]. The crisis of modern technogenic civilization is manifested in the fact that the achievements in the field of military technology, weapons of mass destruction cause the problem of the survival 
of mankind if there happens a war on earth. Thus, the very foundations of human existence are threatened.

The modern crisis of civilization is a contradiction between the growing needs of society and the capabilities of the natural environment to satisfy them. Without resolving it, it is impossible to make the transition of world civilization to sustainable development. It is today that the problems and prospects of modern civilization acquire a special meaning due to the contradictions and problems of the global order, which are becoming more and more acute.

In our country, there is no concept and phenomenon of social class and in connection with the brutal market economy people are faced with a terrible degradation of the economic, social, humanitarian, intellectual foundations of society. This situation inclines us to the need to choose ways to change it based on humanistic values, overcoming moral and ethical degradation. And this task now seems to be becoming one of the most acute philosophical problems of modern society. I would also like to emphasize that the distance from the cultural traditions of our people is noticeable in the activities of young people in the regions of our country. The way out of this situation is through a return to the moral ideals of the peoples of Russia, which are based on centuries-old Orthodox, Islamic traditions that are firmly woven into the millennial culture of the peoples of the country.

At present, Russia has been affected by the crisis of humanism, and at the same time we are witnessing an anthropological crisis, that is, a crisis of man.

Soviet orientalist N.I. Konrad wrote that at present man has come to master the most intimate, the greatest forces of nature, and this has put him in front of an acute question - a question about himself. Who is he a man, mastering the forces of nature? Humanism is that great beginning of human activity, which led up to sire man on the path to progress. Nature should be included not only in the sphere of human life, but also in the sphere of humanism. The most decisive humanization of the entire science of nature is necessary and without this our power over the forces of nature will become our curse. It will emasculate a person from his human principle [1, p. 484]. It was written by him in the 60 -s of the last century and these thoughts are very relevant to this day.

Today technocratism is becoming a global characteristic of human thinking and activity. It has a deep tradition in the public consciousness, which is associated with science, thinking of modern times, with a change in the nature of human activity and the emergence of a real threat of deformation of human nature. The technocratic approach does not allow us to consider a person as an integral system because it is based on one-sided consideration of him, in part, it is characterized by one-dimensionality, "linearity" of thinking and activity, and these parameters are programmed in it.

Technocratism breaks the connecting link of all human relationships, social institutions, products of labor and creativity, it kills the most important thing i.e. the spirit of creativity, love, joy, the meaning of life, replacing it with impersonal obedience, dead social structures, impersonal power and laws. In such a society there is no place for a person who still has a soul with eternal values. An example of such an approach is the situation described by A. Huxley in his novel "Brave new world" [3], which describes technologies that reveal the human world, organized on the basis of artificially created people with programmed, ranked abilities that have the name alpha, beta, epsilon, etc.

The lives of these people are programmed. They forget about the beautiful, do not feel any inspiration from work or to create something new, they do not see the moral benefit because it is a burden for them. To be moral becomes meaningless for the person of the organization since they are a part of a larger immoral "machine society" - the technopolis. The eternal true laws of morality and beauty based on the common good do not fit into it. Plato fought for these principles (recalling his aphorism "Justice is the highest law of the state") and I. Kant 
expressed another thesis: " Act as if the maxim of your actions were to become through your will a general natural law!"

The technocratic mind also gave birth to the eternally bored human consumer for whom values are contained only in material wealth and equipment. How can we make a turn to our fundamental foundations, to our spiritual essence, which preserved the unity of an ethnos or a nation? And is it possible? These issues require detailed analysis and deep study. We need a concept that would allow them to thoroughly work out, and it presupposes a worldview that would lead modern people not to the organization of the wonderful artificial world described by A. Huxley, but to a world that would preserve the basic values on which humanity was formed.

As you know, the modern worldview is purely Western, the people of the world are dominated by the Western style of thinking based on material values, which is purely hostile to Eastern traditions. Now the question is if the East preserve its social and cultural values under the influence of the West or the struggle between them lead to the downfall of all mankind? Both these opposite possibilities are being actualized in the East today. It is possible that the spiritual force present in the tradition can prevail over the material force. It is difficult to foresee when this will happen. However, before that, there may be a period of aggravation of the crisis between Western and Eastern values, which may well lead to complete darkness.

The possibility that such an event may occur in the near future is indicated by the mixing of peoples and cultures that has swept over the West, aggressive Western values that increasingly spread in the East, high technologies that squeeze the sacred doctrine, which will be locked into some kind of shell. And it will be able to get out of it in a new world, but not in a marvelous artificial, but in one where the ideas of transhumanism, spiritual and cultural brotherhood of peoples and nations will be widely developed.

Undoubtedly, transhumanism as a philosophical doctrine calling for the improvement of health, emotional qualities and mental abilities of a person using high technology is attractive. It takes more and more creative minds, daring personalities. Nowadays, more and more creative, active individuals are occupied with developments aimed at ridding people of cancer, aging, and death. Many of them express the idea of building artificial intelligence, a kind of computer that could replace the human brain. Considering that such a transformation is unrealistic, we believe that robotization, artificial intelligence (Al) are the consequences of the development of high technologies and practical development, the economic effect is quite obvious. Supporters of the possibility of transferring the human mind to computers believe that this idea will supposedly allow them to acquire immortality, which is impossible not to be a realizable project, although intellectual achievements, scientific and technological progress orients human creativity to achieve such a result.

Even if we assume that it is possible to replace natural intelligence with an artificial one, replacing a person with a robot, then we will not deal with a person who was formed in the course of his natural evolution, but with a cyborg, a kind of machine-human hybrid that will be devoid of moral, humanistic values, cut off from the whole history of the formation of spiritual culture. Emotional experiences will be alien to it and this robot is unlikely to have a taste of food, not to mention noble sentiments.

\section{Лumepamypa}

1. Конрад Н.И. Запад и Восток: сборник статей. М.: Наука. 1972. 496 с.

2. Степин В.С. Цивилизация и культура. СПб: СПбГУП, 2011. С. 94.

3. Хаксли О. О дивный новый мир. АСТ. 2020. 350 с. 
4. Akaev V. Ethnocultural diversity and consolidation of Caucasus people unity: theoreticmethodologic analysis // Научный альманах стран Причерноморья. 2016. № 3. http://science-almanac.ru

\section{References}

1. Konrad N.I. Zapad i Vostok: sbornik statey [West and East: a collection of articles]. Moscow: Nauka. 1972. 496 p. (in Russian).

2. Stepin V.S. Tsivilizatsiya i kultura [Civilization and culture]. Saint Petersburg: SPbGUP, 2011. p. 94 (in Russian).

3. Huxley A. O divnyy novyy mir [Brave new world]. AST. 2020. 350 p. (in Russian).

4. Akaev V. Ethnocultural diversity and consolidation of Caucasus people unity: theoreticmethodologic analysis. Science almanac of Black Sea region countries. 2016. No.3. 